\title{
POST-EVENT VISITS AS THE SOURCES OF MARKETING STRATEGY SUSTAINABILITY: A CONCEPTUAL MODEL APPROACH
}

\author{
Hui Li ${ }^{1}$, Wei Song ${ }^{2}$, Roger Collins ${ }^{3}$ \\ ${ }^{1}$ International College of Business \& Technology, Tianjin University of Technology, \\ No. 24 Building, No. 391, Binshuixi Rd. Xiqing District, Tianjin City, 300384, P. R. China \\ ${ }^{2}$ School of Business, Black Hills State University, 1200 University St. Unit 9007, \\ Spearfish, 57799 United States \\ ${ }^{3}$ School of Business and Economics, Thompson Rivers University, \\ 900 McGill Road, Kamloops, British Columbia V2C 0C8, Canada \\ E-mails: ${ }^{1}$ lhsnow@163.com; ${ }^{2}$ wsongusa@gmail.com (corresponding author); ${ }^{3}$ rcollins@tru.ca
}

Received 03 April 2012; accepted 06 June 2012

\begin{abstract}
While extant literature has mainly concentrated on contemporaneous event tourism marketing (i.e., on visiting the city during or around the event) and on intentions to revisit after the event's completion, this research investigates the impact of the event on the decisions of potential tourists/visitors who have never visited the host city and want to visit it after the event's completion. Research in this area, especially in those emerging markets where event marketing is developing rapidly, is limited. In order to address the issues raised, a conceptual model is proposed. This model is based on a multivariate research approach, examining the interrelationships between event image, destination image, participants' perceived satisfaction with the event and intentions to visit, under the context of non-repeat event marketing. Five hypotheses postulating these interrelationships were tested using structural equation modeling. A "non-repeat" event, the National Games, the biggest traditional sports event in China, was chosen to test this model. Selfadministered questionnaires were used to collect data relating to a period of two months after the event's completion. The findings show that the sustainability of event marketing strategy can be achieved through the post-event visit to the host city.
\end{abstract}

Keywords: non-repeat event marketing, destination brand image, perceived satisfaction with the event, intentions to visit, long-term tourism effect, brand image transfer, post-event visit.

Reference to this paper should be made as follows: Li, H.; Song, W.; Collins, R. 2014. Post-event visits as the sources of marketing strategy sustainability: a conceptual model approach, Journal of Business Economics and Management 15(1): 74-95.

JEL Classification: M16, M30, M31.

\section{Introduction}

In recent years, destination marketers have focused on event marketing. There has been increasing awareness of the potential financial benefits of events to local tourism marketing development (Getz 1997; Chalip 2006; Berridge 2007; Taks et al. 2009; 
Crowther 2010b; Fourie, Spronk 2011). Events have been part of a set of destination attractions and new tools to attract tourists (O'Brien 2006; O'Brien, Gardiner 2006). From a tourism marketing perspective, events can be divided into two types; the first type is the repeat event, which is hosted in the same place many times in succession; examples of such events are Rio de Janeiro's Carnival, New Orleans' Mardi Gras celebration or, on a more modest scale, Canada's celebration of Groundhog Day in Wiarton, Ontario. The second type of event is the non-repeat or one-time event, which, after being hosted once in a place, will not return for many years, if ever. Most non-repeat events are influential events such as the Olympic Games, the Asian Games, World Expo and the World Cup of soccer, etc. These events are difficult to bid for and often require immense inputs of resources, but are promoted as generating certain profits from tourism for the host cities during the event activity period. Such promotional activity notwithstanding, some host cities were encumbered with great debts after the completion of their hosting of non-repeat events. It is therefore necessary that destination marketers pay attention not only to the profit gained in the short, heavily funded period of the event itself but should also focus on capitalizing upon the benefits generated by the event on a long term basis. Drawing on the existing literature, this study proposes that sustainable tourism profits yielded from non-repeat events are mainly rooted in the positive effects that such events have on the brand image of the destination. Given that the destination image is comprised of the comprehensive cognition of the destination, potential customers to cities which benefit from a non-repeat event will have their desire/intentions to visit influenced in a positive way. Therefore, the relationship between events and destination brand image is the key part of research into the long-term tourism effect of non-repeat events. Existing literature concentrates mainly on event tourism, i.e., on visits made during the event and on intentions to revisit after the event's completion, but not upon the impact of the event and on the decisions of potential tourists (those who were never previously interested in visiting the city but who now want to visit it after the event's completion). This paper identifies the factors affecting visits made after the event's completion. Thus, the decision making process of those tourists with no past experience of the destination becomes crucial. By examining the interrelationships between event images, destination brand image, perceived satisfaction with the event, and intentions to visit, this study proposes a theoretical model of the sustainable tourism impact of non-repetitive events.

\section{Literature review}

\subsection{Event marketing}

Since the 1960s, event tourism marketing has been studied by scholars. Getz (1991) regards events as "an opportunity for leisure, social or cultural experience outside the normal range of choices or beyond everyday experience". This definition is accepted and quoted by most scholars and researchers. A well implemented event marketing strategy is the basis for the "value creation spaces" that an event generates (Crowther, Donlanis 2011) while event marketing is a central path to reach the target customers (Kapustina, Reshetilo 2011). 
Events can be divided into two types; one is repetitive, and is hosted in the same place on many successive occasions; the other is non-repetitive and is hosted only once in any given place (Kellett, Hede, Chalip 2008; Taks et al. 2009). An example of the first type of event would be the Glastonbury Festival - a music festival held in the English town of Glastonbury since 1970. Non-repetitive events are of two types: “one-off” events, which occur only once (for example, the state funeral of Winston Churchill) and regular events - such as the Olympic Games - that are hosted in different locations. This paper will focus on regular non-repetitive events, which are held regularly but in a different location on each occasion.

The main reason for a city to hold events is to attract more tourists in order to maximize the returns from the staging of the event. Such returns are normally expressed in terms of financial benefits. In the research annals of event tourism there are many opinions on the purpose of a city holding "event". Some scholars believe that the main purpose is to build destination image (Vaughan 2001; Kotler 2004; Smith 2006; Crowther 2010b); some believe the main purpose is to enhance the media exposure and to draw attention of medias to the host city (Ritchie, Smith 1991; Chalip et al. 2003; Kim, Petrick 2005). Others believe that the principal purpose is to change the attitudes of tourists to the host city and to increase the competitiveness of the city (Ahmed 1996; Bramwell 1997); yet others think that it is to improve city's infrastructure and to add tourism attractions (French, Disher 1997; Spilling 1996). In this paper, we propose that all of these, including enhancement of media exposure, improvement of infrastructure, creation of new tourism attractions, etc., are methods to achieve the basic purpose, and that the basic purpose of a city holding events is to attract more tourists to visit the city. In other words, the main reason for holding events is to attract target customers and thereby to increase the possibility of being chosen as a destination by tourists (Lee 2006; Kellett, Hede, Chalip 2008). All events marketing strategies should be carried out with this purpose in mind.

\subsubsection{The short-term tourism effect of events marketing}

The short-term tourism effect is the most intensively studied field of tourism research. Event tourism has prompted the creation of a new area of study. Event tourism is an activity that combines event watching and traveling (Gupta 2003; Getz 2007). Tourists visit the host city during the hosting period in order to take part in events, either directly (the minority) or (the majority) as spectators. Event tourism is driven by spectacle offered by the event itself and also by with the important secondary motive of relaxation (Crowther 2010a). In event tourism, the prime motivation of attendees at events is to take part in the events as spectators. Scholars have studied event tourism from many different perspectives. For example, Ritchie and Beliveau (1974), Kang and Perdue (1994), Higham and Hinch $(2002,2003)$ discussed tourist infrastructure and found that the host city can increase the aggregate number of visitors a city attracts, improve tourist infrastructure and reduce the seasonality of tourist visits by hosting events. Nicholson and Pearce (2001), McKercher and Wong (2004), Scott and Turco (2007) studied visitor motivations during events and found that there are certain relationships among event 
type, event size, visitor motivation, and visit behavior, and that there are differences in the decision-making process of first-time destination visitors and repeat destination travelers. Otto and Ritchie (1996), Ruyter et al. (1997), Wooten and Norman (2009) suggested that there is a relationship between visitor experience and visitor satisfaction, and measured visitor's expectation and actual traveling experience; they believe that experience will influence visitor satisfaction. In turn, visitor's perceived satisfaction will influence intentions to revisit and also intentions to initiate word of mouth (WOM) communication on the topic if a visit to a given venue or event. Ritchie and Smith (1991), Zhang et al. (1998), Dwyer et al. (2000), and Trail and James (2001) conducted research on the relationship between event media exposure and "intention to visit" of visitors and believe that the increase in media exposure generated by events will attract more tourists to visit.

\subsubsection{The long-term tourism effect of events marketing}

Some scholars have studied the long-term value of tourism that events can bring. Such value is embodied in the following principal aspects.

Firstly, the host city can improve its infrastructure because of hosting events, especially large and influential sports or culture events. To improve its chances of hosting such an event the host city may choose to improve facilities, not only in sports or cultural venues, but also in terms of infrastructure (Cunningham, Beneforti 2005; Fourie, Spronk 2011). Infrastructure enhancements, urban redevelopment projects and the existence of a large number of specialist venues enrich the visual image of the city, fosters competitiveness and promotes the image of the city. In addition, improvements to infrastructure cannot only increase the capacity and accessibility and promote the security of the host city, but also improve visitor satisfaction, boost reputation, and improve the destination's brand image (Gallarza et al. 2009).

Secondly, the host city can increase its media exposure by hosting events. The host city will publicize the event and the city together in various ways. The city's media exposure will increase because the event has been hosted. It is beneficial to increase brand awareness and recognition of the host city as a tourist destination (Xing, Chalip 2006; Taks et al. 2009). Positive visitor and media evaluations are valuable because they can help to build connections between tourists and cities, and inspire tourists to choose the city as a destination (Pearce 1993; Madrigal 1995; Green, Chalip 1998; Green et al. 2002). Media coverage of events will improve the tourism image of the host city and exert a long-term influence on the tourism economy (Ritchie, Smith 1991; Dwyer et al. 2000). Meanwhile, along with the continuous exposure of the host city and event, tourists who have visited the city before may acquire the desire to revisit. Of course, whether they can revisit depends on many factors (Petrick et al. 2001).

The impact of tourism on host cities is demonstrated in Figure 1. Impacts may be divided into two kinds - long-term and short-term. The short-term effect is connected with tourism relating directly to the event, and focuses on increasing tourism over a short period of time. The long-term effect is connected with the destination brand image; it focuses on the promotion of the city's brand image during events and then attracts more 


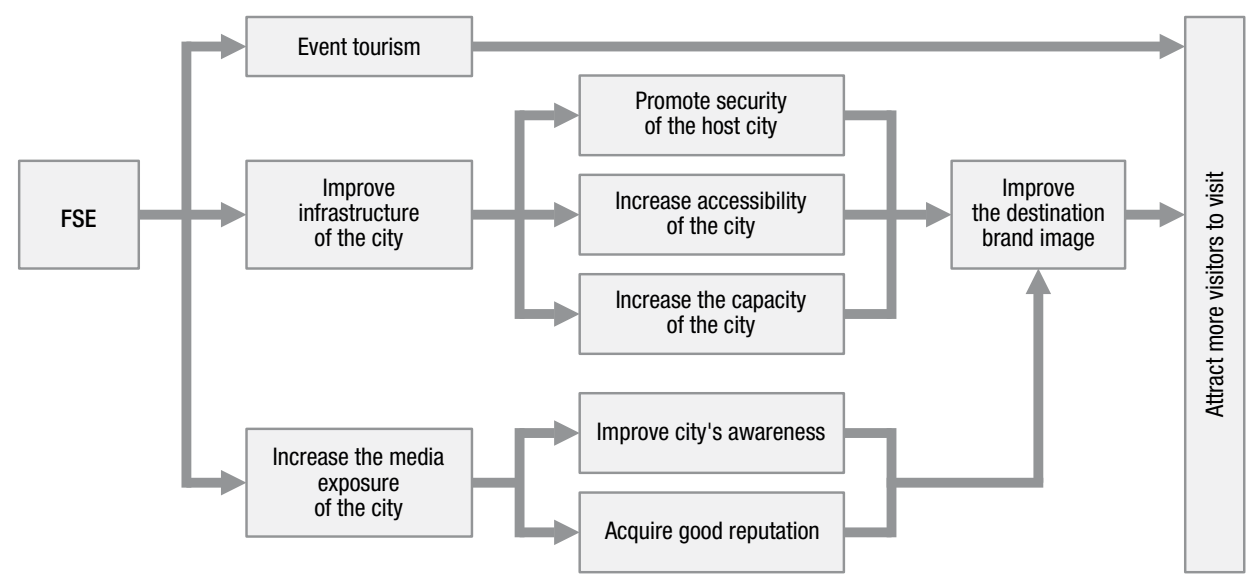

Fig. 1. The tourism effects of events on the host city

tourists to visit in future. Existing literature has largely focused on the short-term tourism effect during the events and has seldom studied the long-term tourism effects, especially those occurring after the events' completion. In addition, most researches have tended to regard repetitive events as the research objects, and focused on the rate of revisit after the event's completion. For non-repetitive events, if the impact that a Festival and Special Event (FSE) engenders could not reach beyond the period during which the event takes place, the tourism effect of events would be short-lived (Jago et al. 2003; Whelen, Wholfeil 2006; Fourie, Spronk 2011). To extend the tourism benefits beyond the event period, strategic planning is required to enhance the host city's attraction as a tourism destination both before, - and particularly after - the event (Bramwell 1997). We can see from Figure 1 that the long-term tourism effect depends mainly on the improvement of destination brand image. Therefore, in order to strengthen or modify the destination brand image, city marketers can strategically incorporate event elements into their promotional campaign, even after the event takes place (Chalip et al. 2003). The essence of leveraging event to improve destination brand image is to transfer elements of the event image to the destination brand image. This is an exercise in co-branding (Chalip et al. 2003), meaning that event brand and destination brand are linked. Brand Image Transfer (BIT) theory is the theoretical basis of this process (See Fig. 1).

\subsection{Brand image transfer}

\subsubsection{The meaning of Brand image transfer}

Brand image, as an important part of the brand asset, has been defined simply as "how customers and others perceive the brand" (Aaker 1996). This perception is held in the consumer's memory and could reflect the consumer's brand associations. When a brand becomes associated with an event, some of the associations linked with event (e.g. youthful, fashionable, relaxing, etc.) may become linked in memory with the brand (Keller 1993). Brand image is a multi-dimensional construct made up of a wider set of 
brand association. It takes place as a result of a number of marketing-related activities and can link two or more brands together. In conceptualizing how the transfer of associations occurs between brands, two theories of consumer learning have been widely used (Smith 2006; Whelen, Wholfeil 2006; Carrillar, Harris, Lafferty 2010). The first is Schema Congruity Theory (Sujan, Bettman 1989). The schema is a cognitive structure that represents knowledge about a concept or type of stimulus, including its attributes and relations among those attributes (Fiske, Taylor 1991). Consumers have preconceived ideas of both the event and brand, and how the event and brand "match up". The greater the match-up perceived, the greater the likely transfer of images (Misara, Beatty 1990; Musante et al. 1999; Ruth, Simonin 2003).

The second theory is the Associative Network Memory Model. It relies on assumptions about how memory operates. In brief, it is assumed that memory consists of individual pieces of information called nodes. When a node is stimulated from rest by a process known as activation, information is recalled from memory (De Groot 1989). "The process whereby one set of nodes (e.g. memory about an event like the FA Cup) prompts thinking about other 'linked' nodes (e.g. AXA insurance, the competition's sponsor) is known as 'spreading activation' - the act of thinking of one concept activates thinking of the other" (Smith 2006). Association among concepts is the origin and basis of BIT (Brand image transfer) theory.

\subsubsection{Meaning movement}

The initial research about BIT concerned the celebrity endorsement process. McCraken (1989) first proposed image transfer theory. He believes that the meaning attributed to celebrities will move from the celebrity endorser to the product (or brand). During this process, culture is a very important factor (Jago et al. 2003; Ohmann, Jones, Wilkes 2006). Celebrity belongs to a specific group with their own cultural features. These features will move from the celebrity endorser to the product by endorsement. Meanings associated with the celebrity become associated with the product in the mind of the consumer. To complete the meaning transfer process, consumers acquire meaning in the product through consumption (Whelen, Wholfeil 2006; Carrillar, Harris, Lafferty 2010).

\subsubsection{Brand extension}

Some scholars believe that image transfer may not be the association among different brands. Brand extension is also a kind of image transfer. Aaker and Keller (1990) believe that brand extensions rely on associations from the core brand transferring to the new brand. For example, Virgin has transferred its image for non-conformity, youthfulness and fun across markets ranging from air travel to cola. It is also a kind of image transfer, but the transfer is only between two brands or among different kinds of products in the same company (Simonin, Ruth 1998; Levin, I., Levin, A. 2000; Xing, Chalip 2006).

\subsubsection{Application of BIT theory in events marketing}

There are two major research directions of BIT between event image and city brand image. 
One is based on the "meaning movement". From this viewpoint, the main purpose in hosting an event is to promote the brand image of the destination and transfer the event image to the destination brand image. Whitelegg (2000) indicated that FSE marketing is an important way to create city brand images. Good evaluations on the FSE can improve the city's brand image, and even change it. For instance, Atlanta has renewed its city brand image through successful events hosting. Newman (2002) suggested that events can resurrect the historical association between business, recreation, tourism and downtowns, and that the destination brand image can be improved by such an association. Smith (2006) focused on holistic image effects, examined whether events pervade images of city destinations, and analyzed how sport event imagery is interpreted by tourists (Jago et al. 2003; O’Brien 2006; Fourie, Spronk 2011). Few scholars focused on the "meaning movement", and most of them conducted the research by semi-structured interviews. Such an approach could make it difficult to generalize the model. By contrast, this study attempts to build a conceptual framework for event marketing strategy.

\section{Hypothesis}

From the literature review it can be seen that the long-term tourism effect of event marketing on the host city is mainly concerned with the promotion of the city's brand image. Among these studies, the most representative one is the co-branding and matchup models that have been put forward by Xing and Chalip (2006). They believe that media coverage of an event can promote the city brand image and that the components of the event image can transfer into the evaluation of city brand image by means of an appropriate marketing mix. This in turn persuades more visitors to visit the city. Meanwhile, the event image may itself be changed by the brand image of successive host cities. This process demands that host city marketers should combine "city brand" and "event brand" together. Xing and Chalip selected three types of event and three kinds of city. A $3 * 3$ (events; time; cities) experimental design was employed, making use of eight virtual advertisements. The results indicated that event image can influence the host city image, which means that BIT takes place. The degree of BIT is affected by match-up degree, involvement, ender and so on. However, the image transfer from city brand to the event is not significant. This research has certain limitations. First of all, the researchers used the experimental method and chose students as their samples, so that the external validity of the results is decreased. Secondly, they did not provide the specific analysis of the factors influencing BIT. Kaplanidou and Vogt (2007) have extended the research of Xing and Chalip (2006). First, they believed that the interrelationship between event image and city brand image exists. Second, they added "past experience of the event or the city" as a variable in the model and believed it should be an influential element of BIT. Third, they believed that the evaluations of event image and host city image as an attitude construct should impact the perceived satisfaction of tourists with the event. Fourth, they divided city brand image into cognitive image and affective image and measured them separately. Fifth, because they thought it to be very difficult to attract new visitors for a city, they chose "intention to revisit" as a behavioral variable in their model. Sixth, they used the follow-up investigation method; 
in order to test whether the intentions to revisit are compatible with the actual behaviors the first survey was conducted during the event, and the second survey was conducted with the same sample a year later. Interestingly, the result indicated that event image has a significant impact on the city brand image, but not the reverse. Neither the past experience nor city brand image has a significant impact on the event image. The event image has a positive impact on the satisfaction with the event, but satisfaction with the event does not have a significant impact on intentions to revisit. Intentions to revisit can however influence significantly the behavior of revisiting. The authors concluded that the main reason for lack of significance is the difference between each type of event. For a repetitive event, hosted in the same place for many successive occasions, the host city image should have a significant effect on the event image. In addition, the past experiences should influence satisfaction with the event and satisfaction with the event should affect the visitor's intention to revisit.

This paper draws on experiences of the research models of Xing and Chalip (2006) and Kaplanidou and Vogt (2007) and follows the research concept of event image - city brand image - intention to visit, taking non-repetitive event as research objects. We believe the results are also suitable to non-repetitive event. Therefore, based on the reviewed literature, the following hypothesis will be tested:

H1: Event image will positively influence the brand image of the host city.

According to attitude-behavior relationships theory, the more positive a customer's attitude to a product, the more positive a perception and favorable a product's image, the more likely it is that those perceptions and image will influence subsequent behavior (Ahmed 1996). This attitude-behavior relationship is also applicable to the concept of city brand image. City brand image is a valuable tool for understanding the destination selection process of tourists and destination positioning strategy (Goodrich 1978; Scott et al. 1978; Stringer 1984; Woodside, Lysonski 1989). There are several studies on the relationship between city brand image and intentions to visit, and their results show that there is a positive correlation between city brand image and behavior intentions. In other words, the more positive a customer's attitude to a city's brand image, the more likely it is that visitors will be willing to visit (Hunt 1975; Goodrich 1978; Milman, Pizam 1995). The choice of a final destination will be based on the total benefit that the destination may bring to the prospective visitors, and that total benefit is derived from experience and from expectations which result from image formation (Gartner 1989). City brand image plays a fundamental role in determining the success of tourist destinations. It can help to make large and complex environments comprehensible and bring about the desire of tourists to visit (Smith 2006). Lapage and Cormier (1977) believed that "in many cases, it is probably the image more than the factual information that produces a tourist's decision on where to travel". A priori perceptions of the city brand image are used by potential visitors to select destination to decide whether they should visit this city. Hunt (1975) stated that "the perceptions held by potential visitors about an area may have significant influences upon the viability of those areas a tourist recreation region". Some scholars studied the influence of city brand image on the decision-making process of first-time destination visitors. The results showed that 
when consumers decide to visit a destination for the first time, city brand image plays an important role (Woodside, Lysonske 1989; Court Lupton 1997; Baloglu, McCleary 1999). In the Kaplanidou and Vogt (2007)'s model, the concept "intention to revisit" was used. In the current paper, more attention is paid to the potential visitors of a city, and so "intention to visit" was chosen instead of "intention to revisit". Consequently, the following hypothesis will be tested:

H2: The city brand image will positively influence intentions of potential visitors to visit the host city.

According to the research of Kaplanidou and Vogt (2007), satisfaction with the event is a very important variable in the overall visit experience. Kaplanidou and Vogt studied tourists' satisfaction with the event after they experienced it (in other words, post-trip). In this paper, we define satisfaction as "the consumer's overall evaluations of the event based on his/her expectation after experiencing it". These experiences include visiting the host city to attend the event during the period of the event and also include the division of visitor time between event and city attractions, where visitors may concentrate on the event to such an extent that they cannot spare time to experience what the destination city has to offer. The positive association between image and satisfaction is a strategic asset (Weigelt, Camerer 1988) and it is also a competitive advantage. Based on the literature review, we found that event image has a positive influence on satisfaction with event (Chon 1990; Pearce 1997). Potential visitors always have expectations as regards the event image before they attend the event. After the event's completion, they will judge whether their expectations are met, according to the information they obtained. If there is a significant negative difference between actual experiences and expectations, they will feel "unsatisfied"; on the other hand, they will be satisfied if the difference is positive. Therefore, in relation to satisfaction, the following hypothesis will be tested:

H3: The event image will positively influence satisfaction with the event.

Kaplanidou and Vogt (2007) supposed there is a positive correlation between satisfaction with the event and intention to revisit. That means, the more visitors are satisfied with the event, the stronger are their intentions to revisit. However, this hypothesis needs to be further justified/verified by more empirical work, especially by studies in those non-Western markets where event marketing research is scarce.

In actuality, any city represents a unique bundle of special tourism goods. The main reason tourists choose to visit a specific city is novelty. Lack of novelty reduces consumers' intentions to revisit. Therefore, the relationship between satisfaction and behavioral intention cannot be verified to an acceptable level of significance. However, for those potential visitors who have never been to the city, the positive correlation between satisfaction with the event and intentions to visit may be significant. For example, they might themselves feel satisfied after visitors to the event show satisfaction with the host city, or pleasant experiences from event visitors is evidenced or the positive outcome of the event is acclaimed/witnessed. They might feel satisfied after they became interested in the event although they have no chance to visit the host city during the host- 
ing period, but have now acquired a desire to visit it in future. Satisfaction has been a strong predictor of behavioral intentions in the post-trip phase (Baker, Crompton 2000). Therefore, in this study, we believe that, for potential visitors, the satisfaction with the event shown by actual visitors or conveyed via media reports can influence intentions to visit. Consequently, the following hypothesis will be tested:

H4: Satisfaction with the event will positively influence behavioral intentions to visit the destination.

In the Kaplanidou and Vogt (2007) model, the relationship between satisfaction with the event and city brand image were ignored. In fact, the satisfaction with the event should influence the evaluation of the city brand image (Gallarza et al. 2009). If the visitor felt satisfied with an event, there might be an association between event and the host city in their minds, and satisfaction with the event will transfer to the host city's brand image (Green et al. 2002). As a result, they might acquire intentions to visit the host city. In other words, if a person is interested in an event, (s)he will be eager to obtain information about it. According to this reasoning, his/her expectations on the event are met and (s)he feels satisfied, then the city's brand image in his/her head might be improved. That is "love me, love my dog". This proposition leads to the final hypothesis:

H5: Satisfaction with the event will positively influence city brand image.

The relationship between the five hypotheses tested in this study is shown in Figure 2 below.

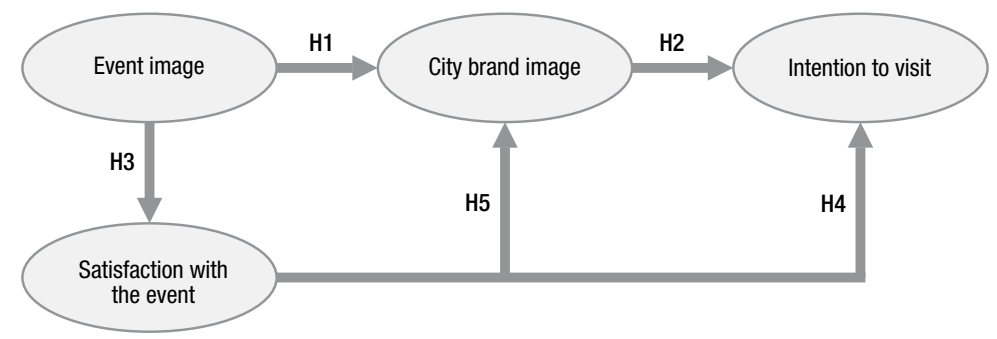

Fig. 2. Diagram showing the five hypotheses to be tested and their relationships

\section{Methodology}

\subsection{Event description}

In order to test the proposed model this study selected the National Games. The National Games is the biggest national sports event in China, and is held in a different city every four years. It is one of most traditional events in China. In previous event marketing studies, most Chinese scholars have been concerned with hallmark events, and always take the Olympic Games, the Asian Games, World Expo and the World Cup, etc. as research objects. These events are popular all over the world and are very famous, and always held in large and internationally renowned cities. So, their research results may lack external validity. The National Games is held in a different city every four years, and more and more medium-size cities or regions not fully developed for tourism have 
a chance to hold this big event. So, we believe the results of this research are applicable to event tourism in general. For this study, we selected the 11th National Games, which was held in Jinan, Shandong Province, China, to test the model.

Jinan is the capital of Shandong Province. It is a historical and cultural city, and is endowed with rich natural tourism resources besides having a fascinating history. In 1998, Jinan was listed as the first of China's Excellent Tourist Cities. In 2006, it was awarded the title of National Garden City. Jinan is known as the "Spring City" for its more than 100 springs. With a watery landscape and quite a number of historical cities in the vicinity, it has always been a tourist attraction through the centuries. However, Jinan is close to Taishan Mountain and Qingdao city (an internationally famous seaside resort city), and its summer is very hot; compared to its rivals, the tourism industry in Jinan is not very developed.

\subsection{Development of scales}

First, based on the scales of Xing and Chalip (2006), Kaplanidou and Vogt (2007) and the characteristic of the National Games, we developed a more complete set of dimensions with which to measure the event image, including stimulating-unstimulating, poor-excellent, healthy-unhealthy, boring-exciting, gloomy-cheerful, valuable-worthless, uglybeautiful, distressing-relaxing, inspiring-uninspiring, and unsupportive-supportive.

Second, we defined city brand image, and agreed with the viewpoint of Prentice et al. (1998) that the city brand image should be measured by visitor's feeling about the city. This feeling originated from the visitor's attitudes and evaluations of the city, and is a psychological linkage between the host city and visitors. The destination image scales were derived from previous studies (Baloglu, McCleary 1999; Lucio et al. 2006) and a review of the destination's promotional material. The scales included 4 items: pleasant, friendly, happy, and passion.

Third, satisfaction with the event scales were derived from the measurement scales which are designed by Ajzen and Driver (1992) and Kaplanidou and Vogt (2007). They included three 7-points Likert items: I am very satisfied with the 11th National Games; the 11th National Games has met my expectations; I believe the 11th National Games is very successful.

Fourth, intentions to visit scales were derived from the measurement scales which are designed by Baker and Crompton (2000) and they included three 7-point Likert items: I was inspired to visit Jinan by the 11th National Games; I have no plans to visit Jinan in the next 2 years if it does not host the 11th National Games; I plan to visit Jinan in the next two years.

Responses were recorded on a 7-point Likert scale, ranging from strongly disagree (1) to strongly agree (7).

\subsection{Data collection}

To test the hypotheses, and to study the long-term tourism effects of event, the survey was conducted 2 months after the event's completion. During a 3-month period, a 
two-page questionnaire survey was conducted in Guangzhou, Shenyang, Beijing, and Nanjing, using the cluster sampling method. In these 3 months, 12 interviewers traveled to these cities to distribute the questionnaires. 150 questionnaires were distributed in each city. All questionnaires were completed face-to-face, and upon completion were immediately returned to the interviewers.

\subsection{Data analysis}

\subsubsection{Sample profile}

In this survey 600 questionnaires were distributed, and a total of 455 were returned. Of those returned, 27 questionnaires were eliminated: 23 questionnaires were returned incomplete or had an excessive amount of missing data, 4 questionnaires had the same answer to all questions. After elimination, 428 questionnaires were coded for data analysis, and the usable response rate is $71.33 \%$.

The sample consisted of $53.7 \%$ males and $46.3 \%$ females, and $66 \%$ of the sample was aged between 18 and 34 years old. Over $46 \%$ of the sample had college degree. Almost half of the respondents (49.53\%) were employees in companies, and $57.7 \%$ respondents had an income less than RMB 2,000.

\subsubsection{Reliability and validity analysis}

In this paper, Cronbach's alpha and Corrected Item-Total Correlation (CITC) were used to measure the reliability of multiple items in a scale. If the number of items is less than 6 , and the Cronbach's alpha $>=0.6$, we believe that the scale has high reliability. If the number of items is more than 6 , and the Cronbach's alpha $>=0.7$, believe that the scale has high reliability. For CITC, we chose 0.4 as the minimally acceptable level to test the scale's reliability. In our survey, all Cronbach's alpha reliability score were more than 0.7, and all CITC exceeded 0.4; it follows that the scales had high reliabilities.

Validity was assessed to see if the indicators were measuring what they were intended to measure. To assure the validity, all scales in this paper were derived from previous scales, and were adjusted according to the specific research background. According to Bogozzi and Yi (1988), if the explained variance for factors is between 0.5 and 0.95 and composite reliability for the factors are more than 0.6 , we believe that this scale has high validities, and the measurement scale has good quality. In our survey, the composite reliability for the factors was more than 0.7 and the explained variance for factors are more than 0.5 , so we can say that the scales had high validities.

\subsubsection{Goodness of fit indices}

The purpose of model evaluation is to test the fit of the model to the data and the significance of the proposed paths between event image, city brand image, satisfaction with the event and intention to visit. If there are latent variables to be measured in a model and especially when multiple dependent variables exist in a model, structural equation modeling (SEM) is a good method to test the fit of the model and the significance of the proposed paths. SEM is especially preferred when testing the multiple relations among 
variables. In this paper, we estimated the fit of the model by using structural equation modeling with AMOS 7.0.

The results revealed a good fit of the model to the data. All fit indices were above 0.9 , and that indicate an acceptable fit (see Table 1).

Table 1. Fit indices of the measurement model

\begin{tabular}{ccccccc}
\hline$\chi^{2} / \mathrm{df}$ & $\mathrm{p}$-level & RMSEA & NFI & RFI & IFI & CFI \\
\hline 2.211 & 0.00 & 0.053 & 0.937 & 0.928 & 0.965 & 0.964 \\
\hline
\end{tabular}

\subsubsection{Path analysis}

Path analysis was used to test the model. Path analysis is a technique used to test causal relationships among a set of non-manipulated variables. For analysis, a path coefficient was considered significant at the .05 or better probability level. In the survey, the standard errors for the factor loadings and path coefficients in the structural model were near zero, and all factor loadings that were tested had t values greater than 1.96. All of the path coefficients were significant (.05 level) (See Fig. 3, Tables 2 and 3). All hypotheses were supported.

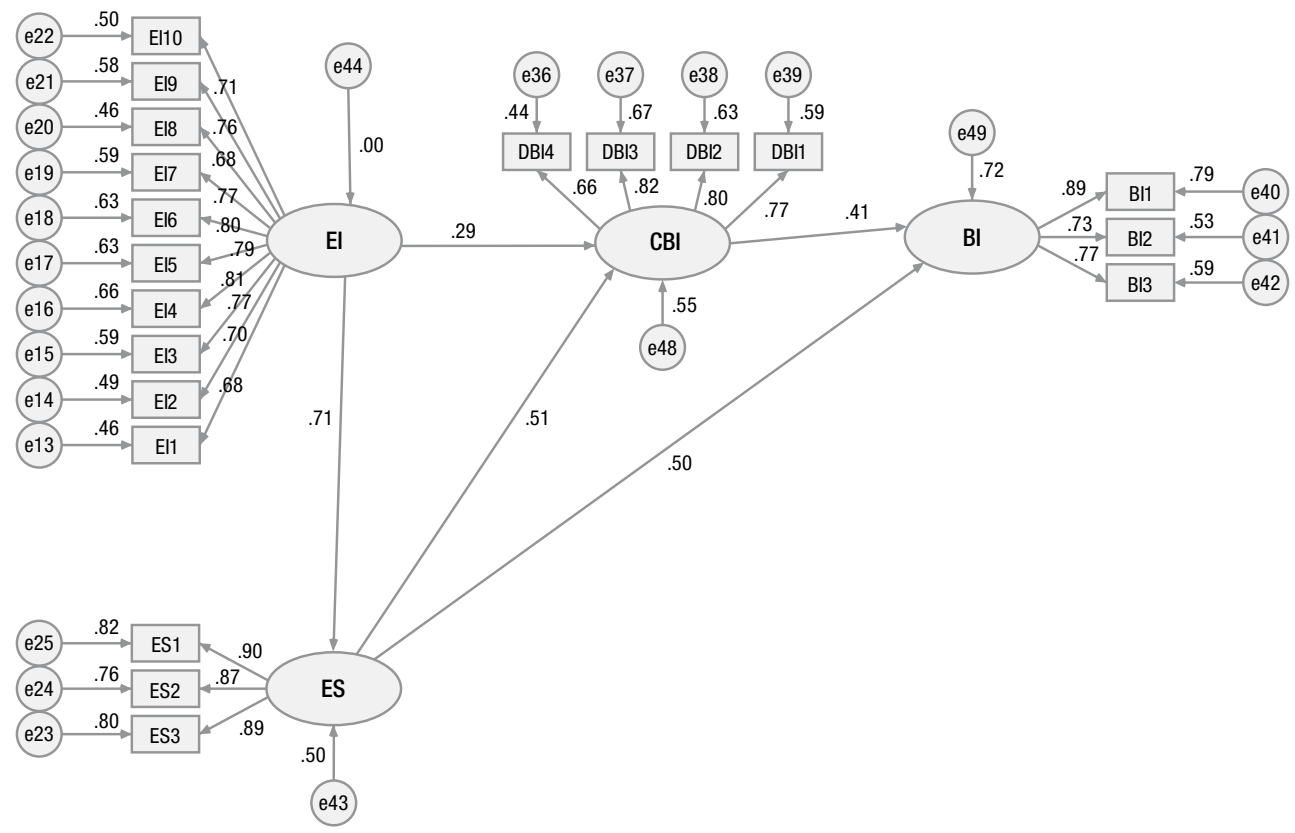

Fig. 3. Standardized parameter estimates 
Table 2. Measurement model factor loading

\begin{tabular}{|c|c|c|c|c|c|c|}
\hline & & Standardized factor loading & Standard error & $\mathrm{T}$ & $\mathrm{P}$ & Results \\
\hline EI1 & $<---$ EI & .679 & & & & \\
\hline EI2 & $<---$ EI & .702 & .069 & 14.575 & $* * *$ & Significant \\
\hline EI3 & $<---$ EI & .769 & .077 & 15.344 & $* * *$ & Significant \\
\hline EI4 & $<---$ EI & .815 & .078 & 14.946 & $* * *$ & Significant \\
\hline EI5 & $<---$ EI & .791 & .076 & 15.017 & $* * *$ & Significant \\
\hline EI6 & $<---$ EI & .795 & .074 & 14.574 & $* * *$ & Significant \\
\hline EI7 & $<---$ EI & .769 & .068 & 12.967 & $* * *$ & Significant \\
\hline EI8 & $<---$ EI & .676 & .068 & 14.472 & $* * *$ & Significant \\
\hline EI9 & $<---$ EI & .763 & .072 & 13.48 & $* * *$ & Significant \\
\hline EI10 & $<---$ EI & .705 & .076 & 14.575 & $* * *$ & Significant \\
\hline ES1 & $<---$ ES & .903 & & & & \\
\hline ES2 & $<---$ ES & .874 & .038 & 26.105 & $* * *$ & Significant \\
\hline ES3 & $<---\mathrm{ES}$ & .892 & .039 & 27.258 & $* * *$ & Significant \\
\hline DBI1 & $<---$ CBI & .766 & & & & \\
\hline DBI2 & $<---$ CBI & .795 & 0.065 & 16.445 & $* * *$ & Significant \\
\hline $\mathrm{DBI} 3$ & $<---$ CBI & .818 & 0.061 & 16.924 & $* * *$ & Significant \\
\hline DBI4 & $<---$ CBI & .662 & 0.065 & 13.477 & $* * *$ & Significant \\
\hline BI1 & $<---$ BI & .886 & & & & \\
\hline BI2 & $<---$ BI & .730 & .049 & 17.215 & $* * *$ & Significant \\
\hline $\mathrm{BI} 3$ & $<---$ BI & .766 & .048 & 18.405 & $* * *$ & Significant \\
\hline
\end{tabular}

Note: EI: Event image; ES: Satisfaction with the event; CBI: City brand image; BI: Intentions to visit.

Table 3. Results of hypotheses tests

\begin{tabular}{llcccccc}
\hline & & Standardized coefficient & $\begin{array}{c}\text { Standardized } \\
\text { error }\end{array}$ & $\mathrm{T}$ & $\mathrm{P}$ & Hypothesis & Results \\
\hline CBI & $<---$ EI & 0.294 & .064 & 4.608 & $* * *$ & H1 & Support \\
\hline BI & $<---$ CBI & 0.413 & .084 & 6.775 & $* * *$ & H2 & Support \\
\hline ES & $<---$ EI & 0.706 & .072 & 12.584 & $* * *$ & H3 & Support \\
\hline BI & $<---$ ES & 0.504 & .063 & 8.659 & $* * *$ & H4 & Support \\
\hline CBI & $<---$ ES & 0.507 & .051 & 7.776 & $* * *$ & H5 & Support \\
\hline
\end{tabular}

\section{Conclusions}

1. For non-repetitive events, event images continue to have a positive influence on the brand image of the host cities for some time after the event

The results of this study support the concept of a positive impact of a non-repetitive event on the city brand image which is coincident with previous findings from Western tourism markets, (e.g., Whitelegg 2000; Xing, Chalip 2006; Kaplanidou, Vogt 2007). 
This indicates that non-repetitive events might extend or enhance the impact on the city brand image although they are hosted only once in a given location. The higher the evaluation assigned to the event image by the non-event visitors, the more do positive comments add to the city brand image. Overall, the path coefficient between event image and city brand image is lower than 0.3 , although the relationship between them is significant. The main reason why it is lower is the characteristics of the event. The National Games is the most representative sports event in China, but it has low influence on the average population, and this factor might lead to less favorable responses, which could in turn have a direct impact on the results of this survey. Nevertheless, even in such a situation, event image still has significant influence on city brand image, and indicates that, for non-repetitive events, positive evaluation of event image does have a positive influence on city brand image.

2. For people who had not visited the event, the relationship between event image, event satisfaction and intention to visit still exists

This study holds that event image positively influences perceived satisfaction with the event, which is consistent with the results of previous research into the satisfaction of spectators who had attended events (Chon 1990; Pearce 1997; Kaplanidou, Vogt 2007). However, the study has extended the Kaplanidou and Vogt's model. In their model, Kaplanidou and Vogt indicated that the relationship between satisfaction with the event and intentions to revisit exists, but the model has not addressed the question of whether satisfaction with the event is also related to intentions to visit the city. In our research, we found that perceived satisfaction with the event has direct influence on intentions to visit the host city. This result shows that potential tourists who have not been in the city would increase their perceived satisfaction with the event if they make higher evaluations on the event image. Their perceived event satisfaction will then enhance their intention to visit the host city. Our finding implies that the influence of satisfaction with the event on intentions to "visit" is stronger than that of the "revisit", as the former's decision is made purely based on the perceived satisfaction with the event, while the latter's decision is influenced by both satisfaction with the event and with the host city. In addition, both our survey and Kaplanidou and Vogt's survey selected regular nonrepetitive events as the research objects. People may be willing to attend future events if they are satisfied with the current event in the host city; then people may visit and pay close attention to another host city which will influence their intentions to revisit. For those repetitive events which are held in the same location for many times, there may be different results. In order to resolve this issue, further research is necessary.

\section{Satisfaction with the event has an influence on city brand image}

In our study, it is found that satisfaction with the event has a positive influence on the city's brand image. This indicates that, the more people are satisfied with the events, the higher the praise to the city brand image people make, and further more influence their future behavioral intentions, even though non-repetitive events are hosted only once in a given location. Such a result is consistent with the results of previous research into the relationship between satisfaction with the event and city brand image of repetitive 
events (Gartner 1993). Whether attending the event during the hosting period, or simply showing an interest in the event, people paid more attention to the events, forming a complicated relationship of image recognition with regard to the hosted cities, storing some emotional elements - such as enthusiasm, friendliness and pleasantness, etc. related to the host cities in their memories (Smith 2006). These images will become ambassadors on behalf of the host city to enhance its reputation amongst visitors influencing their future touring decisions.

\section{Management implications}

Our study can also offer some important implications for management. First, the sustainable strategy of event marketing should include both visitors and re-visitors in order to maximize the financial and social benefits for the event organizer and for the host city concurrently. To extent, the post-event visitors could make greater economic contribution to the host city than re-visitors, who, as they have already had the experience with the host city, would presumably stay a shorter period of time and spend less money. As a consequence, marketing the attractions of a post event visit to the host city would reinforce that city's brand image. Secondly, potential population of post-event visitors would be larger than the re-visitors after the event, thus implying that the sustainable event marketing effort can be more effective if directed at first-time post-event visitors than at the re-visiting or flow-on tourism activities (re-visiting around the end of event, Taks et al. 2009) when seeking to gain economic advantage. This would especially be the case in China's event market, where event visitors tend to visit places they have not previously visited; for this reason, targeting the first time post-event visitor segment becomes extremely important. Thirdly, the satisfaction with the event leads to the possibility of a positive experience of the host city, increasing the probability that an individual would choose to visit other host cities before or after the same or similar event took place. This follows from the fact that brand image can be transferred from the event to the city and then, by means of the same or similar events, to other host cities. Thus, sustainability of event marketing strategy can be achieved.

\section{Limitation of the study}

Some limitations of the research have been identified. Because it is a sports event with Chinese characteristics, the National Games is selected as our research object in this study. However, non-repetitive events are not limited to large-scale and regular nonrepetitive events; they also include other small-scale events or one-off non-repetitive events. Different events may produce different research results. Therefore, the generalizability of our study results to all types of non-repetitive events and cities still requires verification.

Due to the limitation of the National Games, the path coefficient between event image and city brand image is lower than 0.3 . Although the relationship between event image and city brand image is significant, the fact that the results are not as strong as expected, may limit the applicability of the study.

Intentions to visit and actual behavior of visiting are not one-to-one correlated. Because of limitations of time and research resources, this paper focused only upon research 
regarding intentions to visit. Measuring the actual visitor behavior, would undoubtedly boost the persuasiveness of the research results.

The authors of this paper intend to conduct research on the long-term tourism effect on host city after the FSE's completion, but two months after the National Games' completion is selected subjectively in our study, which has impact on the punctuation of the results.

\section{Future studies}

Because of the limitations of this study, the following aspects should be focused upon in future research:

- Expand the study scope, and make comparisons between the consistency and discrepancy of the results;

- Continue the study and attempt to discover the relationship between intentions to visit and actual visiting, and to improve the results;

- Attempt to measure this model using different time periods after the event' completion, such as one week, one month, three months, or six months; then to compare these results and explore the influence of elapsed time on intention to visit;

- Attempt to apply the research results to different customer segments, and contrast the differences between such segments. Example segments would be tourists who are zealous followers of the event (the tourists who had not been in the scene due to some special reasons but pay special attention to the events) or tourists who are related to the city in some way (possibly, tourists who have their close relatives and friends in this city, or who had been in the city several years ago but not visited this city during games), etc.

\section{References}

Aaker, D. A.; Keller, K. L. 1990. Consumer evaluations of brand extensions, Journal of Marketing 54: 27-41. http://dx.doi.org/10.2307/1252171

Aaker, D. A. 1996. Building strong brands. New York: Free Press.

Ahmed, Z. U. 1996. The need for the identification of the constituents of a destination's tourist image: a promotional segmentation perspective, Tourism Review 51: 44-57.

http://dx.doi.org/10.1108/eb058223

Ajzen, I.; Driver, B. L. 1992. Application of the theory of planned behavior to leisure choice, Journal of Leisure Research 24: 207-224.

Bagozzi, R. P.; Yi, Y. 1988. On the evaluation of structural equation models, Journal of the Academy of Marketing Science 16(Spring): 74-94. http://dx.doi.org/10.1007/BF02723327

Baker, D.; Crompton, J. 2000. Quality, satisfaction and behavioral intentions, Annals of Tourism Research 27(3): 785-804. http://dx.doi.org/10.1016/S0160-7383(99)00108-5

Baloglu, S.; McCleary, K. W. 1999. A model of destination image, Annals of Tourism Research 26(4): 868-897. http://dx.doi.org/10.1016/S0160-7383(99)00030-4

Berridge, G. 2007. Event Design and Experience. Oxford: Butterworth Heinemann.

Bramwell, B. 1997. Strategic planning before and after a mega-event, Tourism Management 18: 167-176. http://dx.doi.org/10.1016/S0261-5177(96)00118-5 
Carrillar, F. A.; Harris, E. G.; Lafferty, B. A. 2010. Fortuitous brand image transfer, Journal of Advertising 39(2): 109-123. http://dx.doi.org/10.2753/JOA0091-3367390208

Chalip, L. 2006. Towards social leverage of sport events, Journal of Sport \& Tourism 11: 109127. http://dx.doi.org/10.1080/14775080601155126

Chalip, L.; Green, B. C.; Hill, B. 2003. Effects of sport event media on destination image and intention to visit, Journal of Sport Management 17(3): 214-234.

Chon, K. S. 1990. The role of destination image in tourism, a review and discussion, Revue de Tourism 45(2): 2-9. http://dx.doi.org/10.1108/eb058040

Court, B.; Lupton, R. A. 1997. Customer portfolio development, modeling destination adopters, inactives and rejecters, Journal of Travel Research 36(1): 35-43.

http://dx.doi.org/10.1177/004728759703600106

Crowther, P. 2010a. Marketing space: a conceptual framework for marketing events, The Marketing Review 10(4): 369-383. http://dx.doi.org/10.1362/146934710X541339

Crowther, P. 2010b. The strategic application of events, International Journal of Hospitality Management 29(2): 227-235. http://dx.doi.org/10.1016/j.ijhm.2009.10.014

Crowther, P.; Donlanis, L. 2011. Value-creation space: the role of events in a service-dominant marketing paradigm, Journal of Marketing Management 27(13): 1444-1463.

http://dx.doi.org/10.1080/0267257X.2011.626786

Cunningham, J.; Beneforti, M. 2005. Investigating indicators for measuring the health and social impact of sport and recreation program in Australian indigenous communities, International Review for the Social of Sport 40: 89-98. http://dx.doi.org/10.1177/1012690205052170

De Groot, A. M. B. 1989. Representational aspects of word image ability and word frequency as assessed through word association, Journal of Educational Psychology, Learning Memory and Cognition 15(5): 824-845. http://dx.doi.org/10.1037/0278-7393.15.5.824

Dwyer, L.; Mellor, R.; Mistilis, N.; Mules, T. 2000. A framework for assessing 'tangible' and 'intangible' impacts of events and conventions, Event Management 6: 175-189.

Fiske, S. T.; Taylor, S. E. 1991. Social cognition. $2^{\text {nd }}$ ed. New York: McGraw-Hill.

Fourie, J.; Spronk, K. 2011. South African mega-sport events and their impact on tourism, Journal of Sport \& Tourism 16(1): 75-97. http://dx.doi.org/10.1080/14775085.2011.576119

French, S. P.; Disher, M. E. 1997. Atlanta and the Olympics, a one-year retrospective, Journal of the American Planning Association 63: 351-368. http://dx.doi.org/10.1080/01944369708975930

Gallarza, M. G.; Arteaga, F.; Floristan, E.; Gil, I. 2009. Consumer behavior in a religious event experience, an empirical assessment of value dimensionality among volunteers, International Journal of Cultural, Tourism and Hospitality Research 3(2): 165-180.

Gartner, W. C. 1993. Image formation process, Journal of Travel and Tourism Marketing 2(2/3): 191-215.

Gartner, W. C. 1989. Tourism image, attribute measurement of state tourism products using multidimensional scaling techniques, Journal of Travel Research 28: 16-20.

http://dx.doi.org/10.1177/004728758902800205

Getz, D. 1991. Assessing the economic impacts of festivals and events, research issues, Journal of Applied Recreation Research 16(1): 61-77.

Getz, D. 1997. Event management and event tourism. New York: Cognizant Communication.

Getz, D. 2007. Event studies: theory, research and policy for planed events. Oxford: Elsevier.

Goodrich, J. N. 1978. A new approach to image analysis through multidimensional scaling, Journal of Travel Research 16(3): 3-7. http://dx.doi.org/10.1177/004728757801600302 
Green, B. C.; Costa, C.; Fitzgerald, M. 2002. Marketing the host city, analyzing exposure generated by a sport event, International Journal of Sports Marketing \& Sponsorship 4: 335-353.

Green, B. C.; Chalip, L. 1998. Sport tourism as the celebration of subculture, Annals of Tourism Research 25: 275-291. http://dx.doi.org/10.1016/S0160-7383(97)00073-X

Gupta, S. 2003. Event marketing: issues and challenges, IIMB Management Review 15(2): 87-96. Higham, J. E. S.; Hinch, T. D. 2002. Sport, tourism and seasons, the challenges and potential of overcoming seasonality in the sport and tourism sectors, Tourism Management 23: 175-185. http://dx.doi.org/10.1016/S0261-5177(01)00046-2

Higham, J. E. S.; Hinch, T. D. 2003. Sport, space and time, effects of the Otago highlanders franchise on tourism, Journal of Sport Management 17: 235-257.

Hunt, J. D. 1975. Image as a factor in tourism development, Journal of Travel Research 13(3): 1-7. http://dx.doi.org/10.1177/004728757501300301

Jago, L.; Chalip, L.; Brown, G.; Mules, T.; Ali, S. 2003. Building events into destination branding: insights from experts, Event Management 8: 3-14. http://dx.doi.org/10.3727/152599503108751658

Kang, Y. S.; Perdue, R. 1994. Long-term impacts of a mega-event on international tourism to the host country, a conceptual model and the case of the 1988 Seoul Olympics, Journal of International Consumer Marketing 6: 205-226. http://dx.doi.org/10.1300/J046v06n03_11

Kaplanidou, K.; Vogt, C. 2007. The interrelationship between sport event and destination image and sport tourists' behaviors, Journal of Sport Tourism 12(3/4): 183-206.

http://dx.doi.org/10.1080/14775080701736932

Kapustina, L.; Reshetilo, T. 2011. The event marketing in car-selling industry in Russia: the experience and the efficiency, International Journal of Management Cases 13(4): 151-155.

Keller, K. L. 1993. Conceptualizing, measuring and managing customer-based brand equity, Journal of Marketing 57: 1-22. http://dx.doi.org/10.2307/1252054

Kellett, P.; Hede, A. M.; Chalip, L. 2008. Social policy for sport events: leveraging (relationships with) teams from other nations for community benefit, European Sport Management Quarterly 8: 101-121. http://dx.doi.org/10.1080/16184740802024344

Kim, S. S.; Petrick, J. F. 2005. Residents' perceptions on impacts of the FIFA 2002 World Cup, the case of Seoul as a host city, Tourism Management 26: 25-38.

http://dx.doi.org/10.1016/j.tourman.2003.09.013

Kotler, N. G. 2004. New ways of experiencing culture, the role of museums and marketing implications, Museum Management and Curatorship 19(4): 417-425.

Lapage, W.; Cormier, P. 1977. Image of camping-barriers to participation, Journal of Travel Research 15: 21-25. http://dx.doi.org/10.1177/004728757701500404

Lee, M. J. 2006. Analytic reflections on the economic impact assessment of conventions and special events, Journal of Conventions \& Event Tourism 8(3): 71-85.

http://dx.doi.org/10.1300/J452v08n03_04

Levin, I.; Levin, A. 2000. Modeling the role of brand alliance in the assimilation of product evaluations, Journal of Consumer Psychology 9: 43-52. http://dx.doi.org/10.1207/s15327663jcp0901_4

Lucio, H. L.; Maria, M. S. R.; Miguel, A. M. T.; Javier, S. G. 2006. Tourism destination image, satisfaction and loyalty, a study in Ixtapa-Zihuatanejo, Mexico, Tourism Geographies 8: 343-358. http://dx.doi.org/10.1080/14616680600922039

Madrigal, R. 1995. Cognitive and affective determinants of fan satisfaction with sporting event attendance, Journal of Leisure Research 27: 205-228.

McCracken, G. 1989. Who is the celebrity endorser? Cultural foundations of the endorsement process, Journal of Consumer Research 16: 310-321. http://dx.doi.org/10.1086/209217 
McKercher, B.; Wong, D. Y. Y. 2004. Understanding tourism behavior, examining the combined effects of prior visitation history and destination status, Journal of Travel Research 43: 171-179. http://dx.doi.org/10.1177/0047287504268246

Milman, A; Pizam, A. 1995. The role of awareness and familiarity with a destination, the central Florida case, Journal of Travel Research 33(3): 21-27.

http://dx.doi.org/10.1177/004728759503300304

Misra, S.; Beatty, S. E. 1990. Celebrity spokesperson and brand congruence, Journal of Business Research 21(2): 159-173. http://dx.doi.org/10.1016/0148-2963(90)90050-N

Musante, M.; Milne, G. R; McDonald, M. A. 1999. Sport sponsorship, evaluating the sport and brand image match, International Journal of Sports Marketing and Sponsorship 1(1): 32-47.

Newman, H. 2002. Race and the tourist bubble in downtown Atlanta, Urban Affairs Review 37(3): 301-321. http://dx.doi.org/10.1177/10780870222185351

Nicholson, R. E.; Pearce, D. G. 2001. Why do people attend events, a comparative analysis of visitor motivations at four south island events, Journal of Travel Research 39: 449-460.

http://dx.doi.org/10.1177/004728750103900412

O'Brien, D. 2006. Event business leveraging: the Sydney 2000 Olympic Games, Annals of Tourism Research 33: 240-261. http://dx.doi.org/10.1016/j.annals.2005.10.011

O’Brien, D.; Gardiner, S. 2006. Creating sustainable mega events impacts: networking and relationship development through pre-event training, Sport Management Review 9: 25-47.

http://dx.doi.org/10.1016/S1441-3523(06)70018-3

Ohmann, S.; Jones, L.; Wilkes, K. 2006. The perceived social impacts of the 2006 Soccer World Cup on Munich residents, Journal of Sport and Tourism 11: 129-152.

http://dx.doi.org/10.1080/14775080601155167

Otto, J. E.; Ritchie, J. R. B. 1996. The service experience in tourism, Tourism Management 17(3): 165-174. http://dx.doi.org/10.1016/0261-5177(96)00003-9

Pearce, D. G. 1997. Competitive destination analysis in Southeast Asia, Journal of Travel Research 35(4): 16-24.

Pearce, P. L. 1993. An examination of event motivations, a case study, Festival Management and Event Tourism 1: 5-10.

Petrick, J. F.; Morais, D. D.; Norman, W. C. 2001. An examination of the determinants of entertainment vacationers' intentions to revisit, Journal of Travel Research 40: 41-48.

http://dx.doi.org/10.1177/004728750104000106

Prentice, R. C.; Guerin, S.; McGugan, S. 1998. Visitor learning at a heritage attraction, a case study of discovery as a media product, Tourism Management 19(1): 5-23.

http://dx.doi.org/10.1016/S0261-5177(97)00077-0

Ritchie, J. R. B.; Beliveau, D. 1974. Hallmark events, an evaluation of a strategic response to seasonality in the travel market, Journal of Travel Research 14(2): 14-20.

http://dx.doi.org/10.1177/004728757401300202

Ritchie, J. R. B.; Smith, B. 1991. The impact of mega-event on host region awareness, a longitudinal study, Journal of Travel Research 30(1): 3-10. http://dx.doi.org/10.1177/004728759103000102

Ruth, J. A.; Simonin, B. L. 2003. Brought to you by brand A and brand B: investigating multiple sponsors' influence on consumers' attitudes toward sponsored events, Journal of Advertising 32(3): 19-30.

Ruyter, K. D.; Wetzels, M.; Lemmink, J.; Mattsson, J. 1997. The dynamics of the service delivery process, a value-based approach, International Journal of Research in Marketing 14(3): 231-243. http://dx.doi.org/10.1016/S0167-8116(97)00004-9 
Scott, A. K. S.; Turco, D. M. 2007. VFRs as a segment of the sport event tourist market, Journal of Sport Tourism 12(1): 41-52. http://dx.doi.org/10.1080/14775080701496800

Scott, D.; Schewe, C.; Frederick, D. 1978. A multi-brand/multi-attribute model of tourist state choice, Journal of Travel Research 17(1): 23-29. http://dx.doi.org/10.1177/004728757801700105

Simonin, B. L; Ruth, J. A. 1998. Is a company known by the company it keeps? Assessing the spillover effects of brand alliances on consumer brand attitudes, Journal of Marketing Research 35: 30-42. http://dx.doi.org/10.2307/3151928

Smith, A. 2006. Tourists' consumption and interpretation of sport event imagery, Journal of Sport Tourism 11: 77-100. http://dx.doi.org/10.1080/14775080600985382

Spilling, O. R. 1996. The entrepreneurial system, on entrepreneurship in the context of a megaevent, Journal of Business Research 36: 91-103. http://dx.doi.org/10.1016/0148-2963(95)00166-2

Stringer, P. 1984. Studies in the socio-environmental psychology of tourism, Annals of Tourism Research 11(1): 147-166. http://dx.doi.org/10.1016/0160-7383(84)90101-4

Sujan, M.; Bettman, J. 1989. The effects of brand positioning strategies on consumers' brand and category perceptions, Journal of Marketing Research 26(4): 454-467.

http://dx.doi.org/10.2307/3172765

Taks, M.; Chalip, L.; Green, B. C.; Kesenne, S.; Martyn, S. 2009. Factors affecting repeat visitation and flow-on tourism as sources of event strategy sustainability, Journal of Sport Tourism 14(2): 121-142. http://dx.doi.org/10.1080/14775080902965066

Trail, G. T.; James, J. D. 2001. The motivation scale for sport consumption, assessment of the scale's psychometric properties, Journal of Sport Behavior 24: 108-127.

Vaughan, R. 2001. Images of a museum, Museum Management and Curatorship 19(3): 253-268. http://dx.doi.org/10.1080/09647770100301903

Weigelt, K.; Camerer, C. 1988. Reputation and corporate strategy, a review of recent theory and applications, Strategic Management Journal 9(5): 443-454.

http://dx.doi.org/10.1002/smj.4250090505

Whelen, S.; Wholfeil, M. 2006. Communicating brands through engagement with "lived" experiences, Brand Management 13(4/5): 313-329. http://dx.doi.org/10.1057/palgrave.bm.2540274

Whitelegg, D. 2000. Going for gold, Atlanta's bid for fame, International Journal of Urban and Regional Research 24: 801-817. http://dx.doi.org/10.1111/1468-2427.00279

Woodside, A. G.; Lysonski, S. 1989. A general model of traveler destination choice, Journal of Travel Research 27(4): 8-14. http://dx.doi.org/10.1177/004728758902700402

Wooten, M. H.; Norman, W. C. 2009. Using the ratings grid in tourism/event management, International Journal of Culture, Tourism and Hospitality Research 3(4): 347-360.

Xing, X. Y.; Chalip, L. 2006. Effects of hosting a sport event on destination brand, a test of cobranding and match-up models, Sport Management Review 9: 49-78.

http://dx.doi.org/10.1016/S1441-3523(06)70019-5

Zhang, J. J.; Pease, D. G.; Smith, D. W. 1998. Relationship between broadcasting media and minor league hockey game attendance, Journal of Sport Management 12: 103-122. 
Hui LI is an Associate Professor of marketing at Tianjin University of Technology, where she teaches courses in international marketing and marketing research. She is the director of Business Administration Department of International College of Business and Technology. She obtained her Ph.D. from Renmin University of China. Her research interests are focused in the area of city branding with emphasis on eco-city branding, event marketing, and tourism. Currently, she is working on the "Study on the Relationship between the Environmental Awareness of the Public and Eco-city Branding", which is funded by Tianjin Philosophy and Social Science Research Planning Projects.

Wei SONG received her PhD in Marketing/Management from the University of Edinburgh, UK. She has had a solid international experience, including teaching at a range of universities and working at a major US corporation. Currently, she holds an Associate Professor post in Marketing at Black Hills State University, USA. Her research interests are in the areas of marketing strategy, consumer behavior, branding and Chinese own brand strategy. She has chaired various sessions at the international conferences and publishes the research papers regularly.

Roger COLLINS is currently an Associate Professor of the School of Business and Economics, Thompson Rivers University, British Columbia, Canada. A graduate of The University of Hertfordshire and of the London School of Economics, he has taught at Middlesex University (UK), and Concordia University (Canada) with visiting positions at California State University - Hayward (USA), Turku Polytechnic University (Finland) and Tianjin University of Technology (People's Republic of China). His interests are accounting and Business Strategy. His current research is into pricing and marketing strategies relating to "rights to display" goods. 